\title{
Il linguaggio grafico modernista nelle pagine di Pencil Points
}

\author{
Manuela Piscitelli
}

\section{Abstract}

L'articolo analizza le caratteristiche e l'evoluzione nella comunicazione del progetto di architettura tra gli anni Venti e Quaranta attraverso lo studio della rivista americana Pencil Points. Gli anni Venti furono un momento di forte impulso nel settore dell'editoria periodica di architettura che divenne uno dei principali canali per il dibattito e la diffusione di nuove idee e immagini. Il linguaggio grafico ebbe negli anni successivi una rapida evoluzione, parallelamente al linguaggio progettuale e alla composizione visiva della pagina stampata. Per questo le riviste coeve costituiscono un osservatorio privilegiato, con un ampio repertorio di immagini e soluzioni grafiche che testimoniano l'evoluzione delle tecniche di rappresentazione e comunicazione dell'architettura. La scelta della rivista Pencil Points è dovuta al lungo arco temporale di pubblicazione, alla sua struttura editoriale ben definita, non legata a una specifica corrente artistica, e alla periodicità regolare, che ha consentito di osservare le trasformazioni nell'ambito della presentazione dei contenuti visivi.

\section{Parole chiave}

linguaggio grafico, architettura modernista, rappresentazione progetto, illustrazioni, periodici.

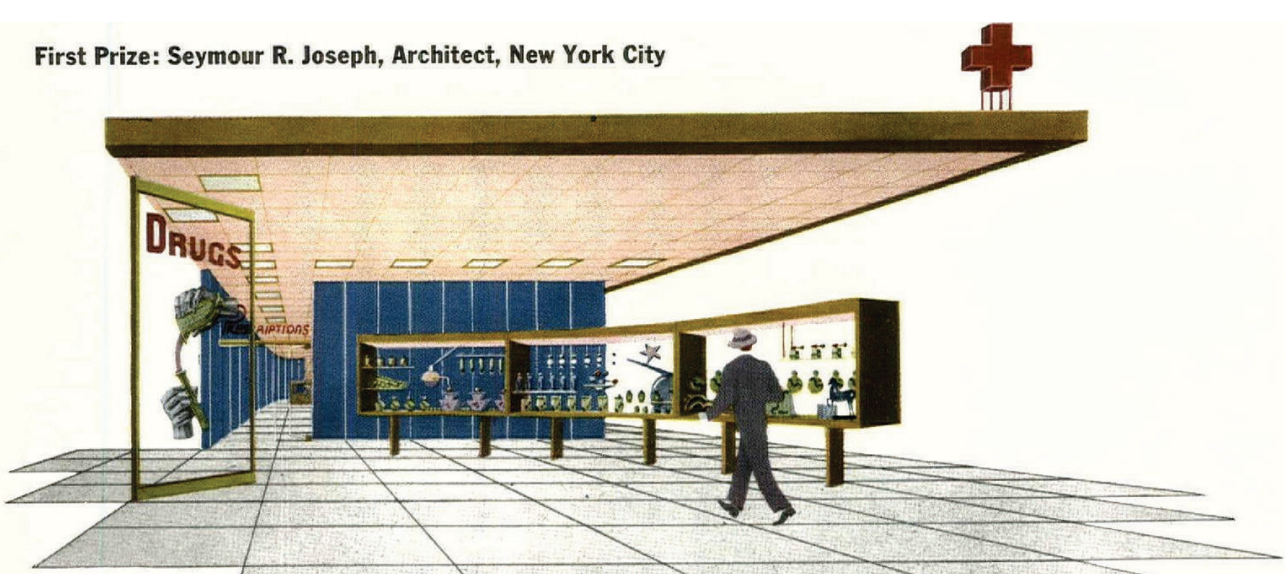


Dalla sua diffusione a fine Ottocento e per buona parte del Novecento, il periodico è stato il media che ha maggiormente contribuito al dibattito culturale in diversi settori, tra cui quello dell'architettura, e alla diffusione di idee, gusti, tendenze, immagini tra aree geografiche distanti. Come scriveva il direttore di Domus nel suo congedo, "una rivista deve essere capace sì, di far vedere e conoscere progetti, prodotti, pensieri che il nostro tempo produce ma, soprattutto, di raccontare le storie che li rendono possibili, le storie che li sottendono" [Di Battista 20 17].

La narrazione innanzitutto implica scelte nei contenuti, ma altrettanto significative sono le scelte delle modalità espressive attraverso le quali questi contenuti sono veicolati, che rendono il loro studio particolarmente interessante per tracciare una storia dell'evoluzione della rappresentazione del progetto architettonico e della sua comunicazione. Dall'analisi di una rivista infatti emergono tematiche quali la progettazione visiva, il disegno grafico, l'utilizzo della fotografia o del disegno di architettura, i rapporti tra immagini e testo. Anche la presenza della pubblicità è un elemento significativo nello studio di un periodico, per la duplice valenza di comunicazione con il pubblico dei lettori e del mondo produttivo, e di sostegno per la rivista.

"I codici in gioco nelle pubblicazioni periodiche sono numerosi: l'impaginazione (quantità dello spazio bianco, numero delle colonne); i caratteri tipografici; il formato del volume; la periodicità (settimanale, mensile, trimestrale, irregolare); la qualità delle illustrazioni (a colori o meno, tipo di tecnologia usata per la riproduzione); la presenza e la collocazione degli spazi pubblicitari; la qualità della carta e della rilegatura; le reti di vendita e distribuzione; le condizioni finanziarie e le eventuali remunerazioni ai contributori; la struttura editoriale; e ancora il tipo dei materiali pubblicati" [Thacker 2017, p. 22].

Il presente studio affronta queste tematiche attraverso l'analisi della rivista americana Pencil Points, la cui notevole diffusione e longevità consente di apprezzare le trasformazioni, sia nel linguaggio grafico proprio della rivista che in quello dei progetti presentati nelle sue pagine, in un arco temporale che copre buona parte del Novecento e vede l'affermazione del linguaggio modernista, che la rivista assunse come tema centrale.

Pencil Points fu fondata nel 1920 come mensile, con l'obiettivo di mettere in relazione disegnatori e architetti. Inizialmente legata all'Accademia delle Belle Arti, fu uno dei princi-

Fig. I. Testo e illustrazioni sull'esecuzione del disegno in prospettiva. 2, luglio 1920

Fig. 2. Warren \& Wetmore Architects, Alzati per il progetto dell'Ambasciata italiana a Washington D. C. a Washington D. C.

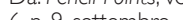
6, n. 9, settembre 1925. || progetto è illustrato attraverso la pubblicazione degli elaborati relativi alle piante dei vari livelli ed $i$ prospetti.
PERSPECTIVE DRAWING, PART II By paul VALENTI

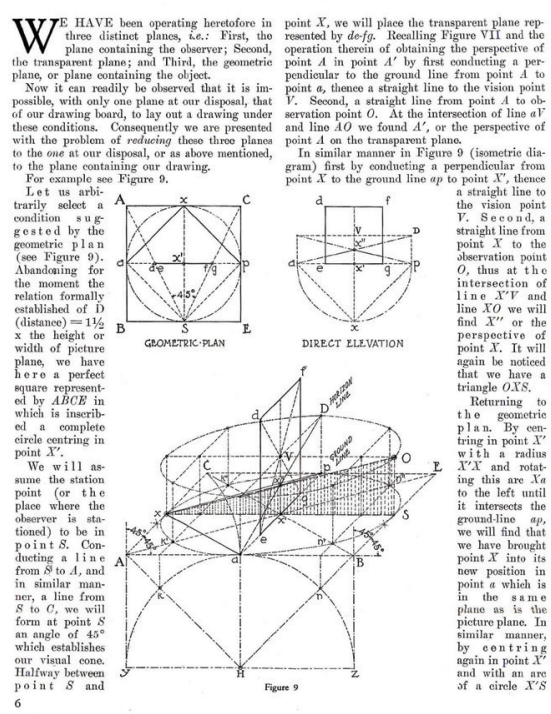

PENCIL POINTS

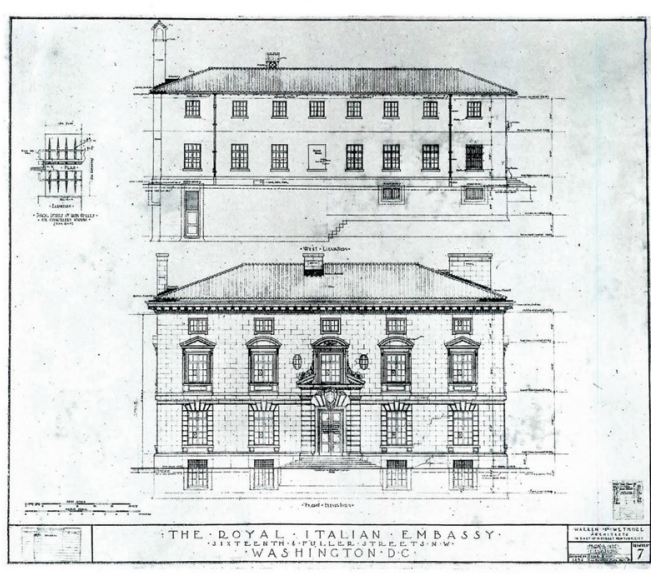

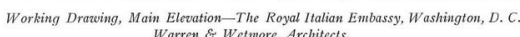


pali veicoli di diffusione delle nuove tendenze del modernismo, testimoniando un particolare momento storico nel settore dell'architettura e del design negli Stati Uniti. Sulle sue pagine, tra gli anni Venti e Quaranta, si snodano la storia e le idee di una nuova generazione di architetti americani ed europei: Russel Pope, Francis Bacon, Walter Gropius, Richard Neutra, Le Corbusier, Marcel Breuer, Norman bel Geddes, Mies Van der Rohe, dei quali veicolò teoria e progetti. Partita con sole 22 pagine nel 1920, dieci anni dopo pubblicava I 52 pagine con una tiratura di 21.000 copie. Nel 1940 era una delle riviste americane di architettura maggiormente distribuite a livello nazionale, accanto ad Architectural record e Architectural forum. Nel 1944 il nuovo titolo Progressive Architecture ne sancì il passaggio a rivista di progettazione e urbanistica. Con questo stile restò una delle più autorevoli riviste di settore per i successivi 50 anni, fino alla chiusura nel 1995 [Hartman, Cigliano 2004]. L'epoca di fondazione di Pencil Points coincide con un momento di grande diffusione della rivista come media per il dibattito architettonico. I maestri dell'architettura, infatti, la scelsero come strumento per la diffusione delle proprie idee, fondandone anche di proprie, come L'esprit nouveau di Le Corbusier (1920-1925) e G: Material zur elementaren Gestal-

Fig. 3. Pencil Points, testata del vol. I n. I, giugno 1920; nuova testata semplificata nel vol. 6, n. I I, novembre 1925; prima copertina nel vol. I0, n. I I, novembre 1929: prima copertina illustrata nel vol. 14 , 1 . gennaio 1933; cambio denta posizione del cha posizione del titolo della testata nella copertina del vol. gennaio 1935.

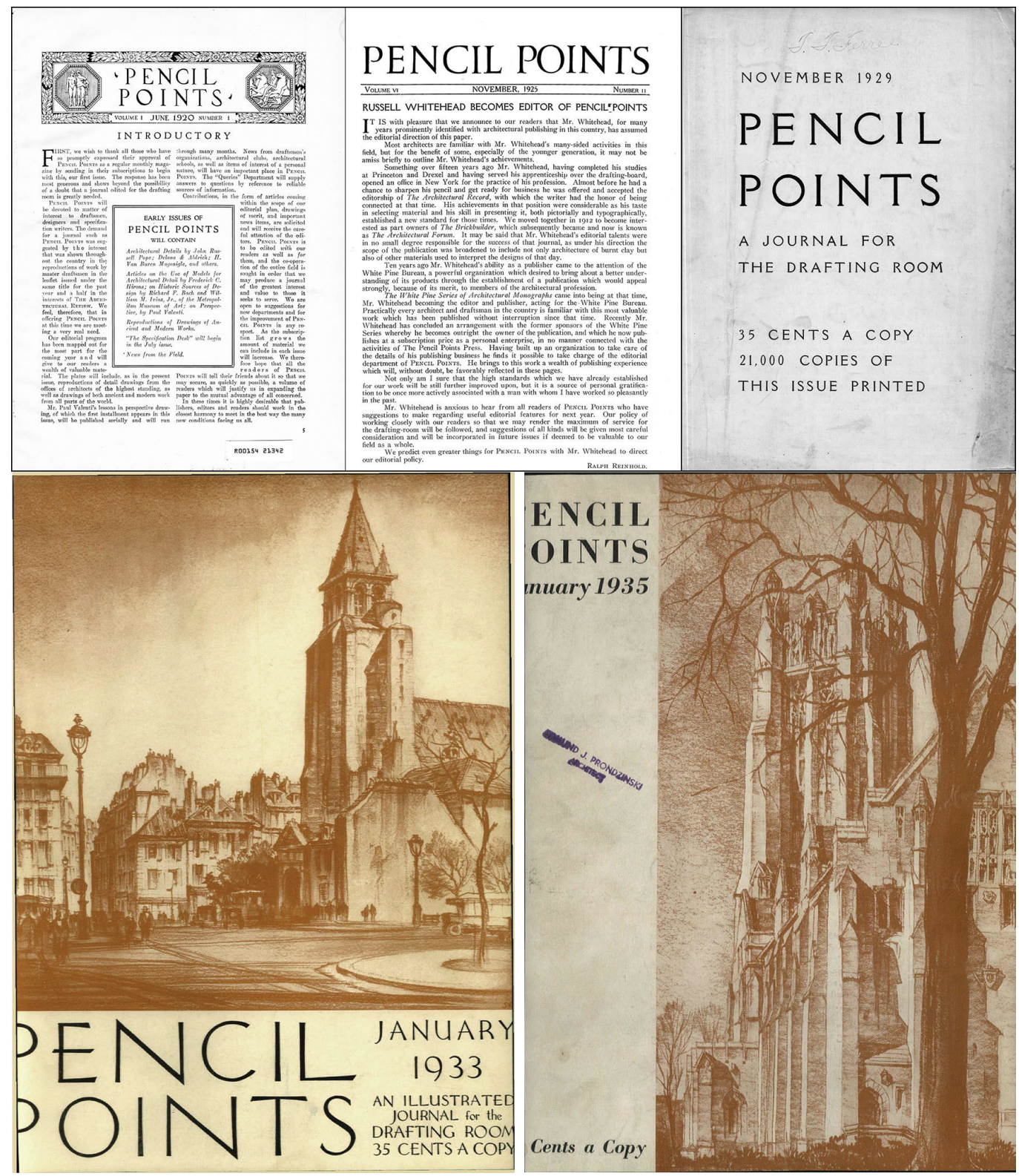


tung di Mies van der Rohe (1923-1926), che furono utilizzate come canale di dibattito per le avanguardie. Mentre L'Esprit Nouveau aveva un'impostazione tipografica tradizionale, in G la ricerca grafica era parte del progetto comunicativo, come dimostra l'impaginato tipografico costruttivista realizzato da El Lissitzky [Mertins 20 I 0]. II fenomeno è largamente diffuso in tutte le aree geografiche in questo periodo, con riviste legate anche ai movimenti artistici e alla diffusione dei loro valori. Accanto alle già citate G e L'Esprit Nouveau, troviamo Bauhaus (1928-1933) in Germania, Sovremennaia Arkhitektura (1926-1930), Lef (1923-1925) e Veshch (1922) in Russia, Wendingen (1918-1931) e de Stijl (1917-1931) in Olanda, e tutti i periodici futuristi in Italia come Valori plastici (1918-192 I), Lacerba (19131915), Noi (1917-1920 e 1923-1925).

Intorno agli anni Venti, dunque, si assiste a un fenomeno molto complesso nell'editoria periodica, caratterizzata da pubblicazioni di breve durata e spesso con periodicità irregolare, accomunate dalla volontà di riunire in un nuovo linguaggio il piano grafico, tipografico e editoriale con i contenuti da veicolare. Le innovazioni estetiche e visuali del cubismo, il superamento della rappresentazione figurativa della realtà, la frammentazione dell'ordine della pagina operato dal futurismo, le sperimentazioni tipografiche del Bauhaus, furono altrettanti elementi che contribuirono in questa fase al rinnovamento visivo dei prodotti

Fig. 4. George D. Recher progetto per un Drug store. Proposta presentat al concorso Modernize main street. Da: Penci Points, vol. 16, n. 10 , ottobre 1935.

Fig. 5. Giuseppe Vaccaro, progetto per il Palazzo delle poste di Napoli. Modello, pianta e prospettiva dell'atrio centrale. Da: Pencil Points, vol. I 6, n. I, gennaio 1936
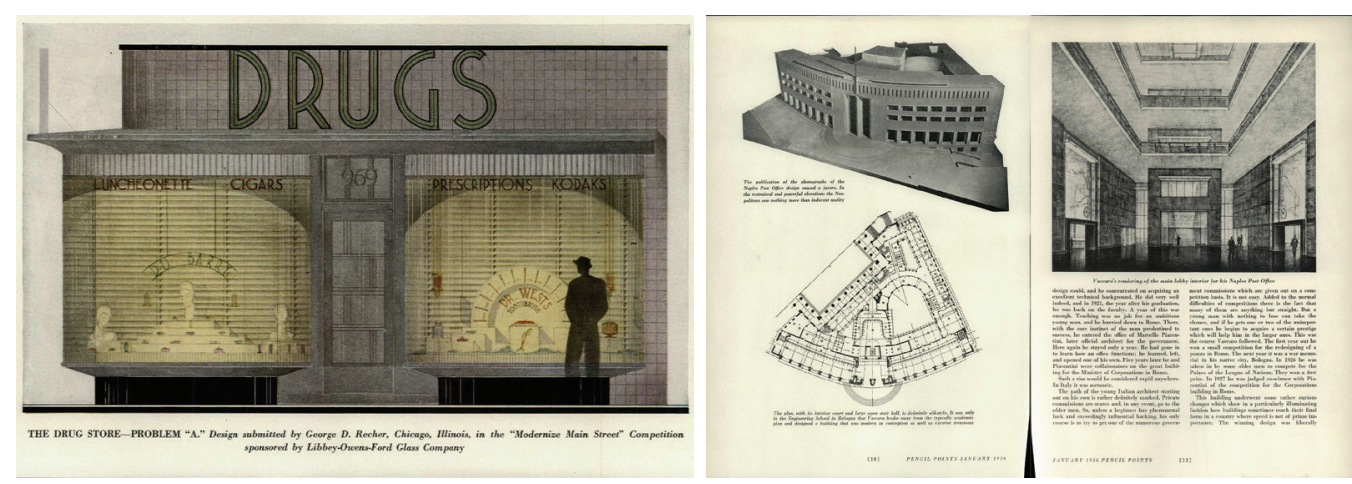

editoriali attraverso i quali le avanguardie comunicavano le proprie idee, e coinvolsero anche il settore dell'architettura [Chinellato e Noventa 2013].

La scelta di non utilizzare queste riviste per la presente indagine è dovuta alla volontà di coprire un arco temporale più lungo, analizzando le trasformazioni in una rivista con una sua struttura editoriale ben definita, non legata a una specifica corrente artistica, e una periodicità regolare, per meglio cogliere le trasformazioni che più in generale hanno caratterizzato la rappresentazione e comunicazione del progetto di architettura.

In questa prima fase, a differenza delle riviste legate ai movimenti di avanguardia caratterizzate da impianti grafici innovativi, Pencil Points presenta un impianto grafico tradizionale, con una gabbia a due colonne, l'uso del capolettera a inizio paragrafo, poche variazioni nei caratteri tipografici. Testi e immagini solo in pochi casi condividono lo spazio della pagina, più spesso i disegni sono stampati in tavole separate, numerate e corredate di didascalie. Poiché inizialmente la rivista si rivolgeva ai disegnatori e all'accademia delle Belle Arti, i temi dei disegni sono spesso di carattere pratico, con illustrazioni per l'impostazione di una prospettiva o l'esecuzione di un disegno, le tecniche grafiche, i consigli sull'uso di matite e china, l'esecuzione delle ombre e chiaroscuri; alternati a riproduzioni di tavole di architettura classica e disegni di progetti di architettura (figg. I, 2). In alcuni numeri viene proposta l'analisi grafica delle geometrie di edifici. La fotografia ha un peso marginale nelle pagine, l'illustrazione è quasi esclusivamente affidata al disegno con le varie tecniche espressive. Riguardo ai metodi di rappresentazione, prevale l'utilizzo della prospettiva sotto forma di schizzo a mano libera o geometricamente costruita. Molto utilizzato è 
anche il metodo delle proiezioni ortogonali, in pianta e prospetto. Le sezioni sono rare e l'assonometria completamente assente.

Dal numero di novembre 1925, sotto la nuova direzione editoriale di Russel Whitehead, comincia un timido tentativo di modernizzazione della grafica della rivista, a partire dalla testata che viene semplificata abolendo i motivi decorativi con un risultato di maggiore concisione e pulizia formale.

L'impianto della pagina continua ad avvalersi della doppia colonna, ma le didascalie delle tavole vengono inserite nella pagina a fronte dando un maggiore respiro alla struttura grafica. Le immagini sono ancora prevalentemente vedute prospettiche.

Dal numero di novembre 1929 la rivista si dota di una copertina vera e propria, anche se priva di immagini ma con le sole informazioni sulla rivista che precedentemente erano inserite nella testata sulla prima pagina. Questa innovazione coincide con un deciso aumento del numero di pagine del volume, dovuto all'inserimento di numerose pubblicità sia all'inizio che in chiusura della rivista. La vecchia testata viene riproposta sulla prima pagina della rivista dopo l'inserto pubblicitario che riempie fino a 60 pagine all'inizio del numero. Le pagine pubblicitarie sono caratterizzate da una maggiore dinamicità nella composizione e nelle variazioni tipografiche, rispetto all'impianto della rivista che resta ancora ancorato alla vecchia gabbia a due colonne con poca integrazione tra testi e immagini.

Dal gennaio 1933, la copertina diventa illustrata. II nome della testata si sposta in basso in posizione allineata a sinistra, posizione che si modificherà diverse volte negli anni suc-

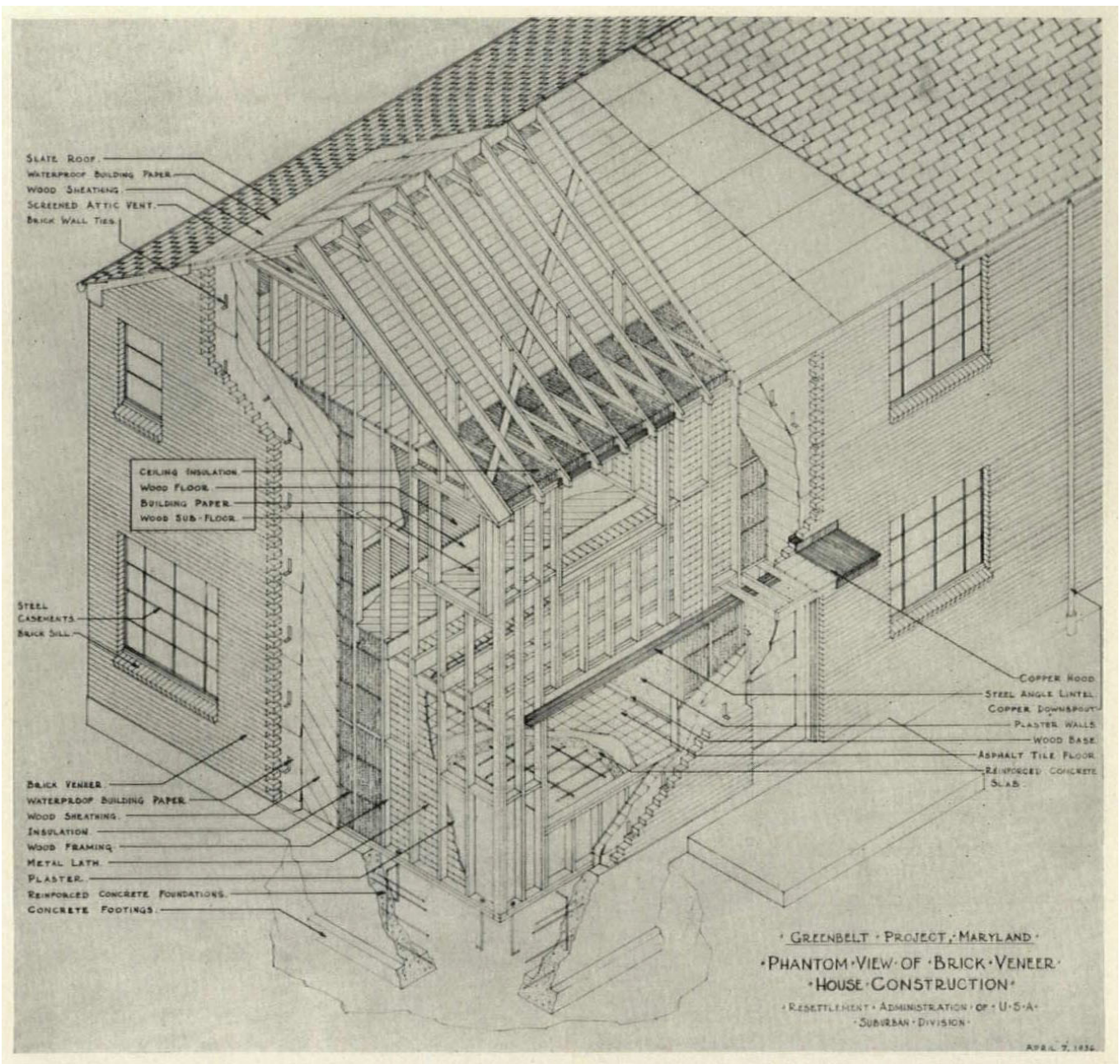


cessivi, lasciando l'immagine come elemento visivo dominante. Si tratta sempre di un disegno eseguito e pubblicato a colori, tipicamente la vista prospettica di un edificio (fig. 3). Allinterno, nonostante i disegni continuino a prevalere, le fotografie acquistano progressivamente un peso maggiore. Negli anni successivi si può notare un allontanamento dalle tematiche rivolte ai disegnatori e una maggiore attenzione ai concorsi di idee e alla presentazione dei progetti di architettura modernista di diverse aree geografiche, contribuendo alla circolazione di idee e immagini (fig. 4). Fu costituita una rubrica dedicata agli architetti europei contemporanei e ai loro progetti. In questa rubrica, il numero di gennaio 1936 presenta l'italiano Giuseppe Vaccaro e ne illustra diversi progetti, tra cui la facoltà di Ingegneria di Bologna e il Palazzo delle poste di Napoli (fig. 5). Gli elaborati grafici illustrativi dei progetti sono in prevalenza disegni e in misura molto minore fotografie. Tra i disegni, prevalgono ancora le viste prospettiche, esterne e interne, accompagnate dalla pianta dell'edificio. Fa la sua comparsa la rappresentazione assonometrica, anche sotto forma di spaccato per mostrare i dettagli costruttivi (fig. 6). Contestualmente l'impaginazione diventa più libera, con maggiore integrazione tra testo e immagini, e la composizione sulla doppia pagina che permette di pubblicare immagini più grandi sfruttando lo spazio delle pagine affiancate. Le copertine abbandonano l'immagine che le caratterizzava, e spesso si limitano a un colore di base e pochi elementi grafici, su cui spicca il nome della testata che diventa l'elemento visivo principale, con un'impostazione più moderna in linea con le tematiche dell'essenzialità dell'architettura modernista che venivano pubblicate. I numeri iniziano a essere dedicati a una tematica o un architetto, come nel caso dei progetti per la Fiera Mondiale di New York del 1939, pubblicati nel numero di dicembre 1936, o il numero di gennaio 1937 in gran parte dedicato a Norman Bel Geddes e i suoi futuristici progetti nel settore dei trasporti. II design irrompe nelle pagine della rivista con modelli di automobili, treni, aeroplani, le prime idee di case mobili. Le fotografie dei plastici e degli oggetti, ripresi anche durante la fase di produzione, cominciano a superare quantitativamente i disegni (fig. 7).

Fig. 7. Norman Bel Geddes, progetto della nuova Prymouth Modeli e schema di confronto con la precedente versione in pianta e sezione. Da: Pencil Points, vol. I7, n. I, gennaio 1937

Fig. 8. Schemi di città del passato e del futuro. Da: The new Pencil Points, n.6, giugno 1942.
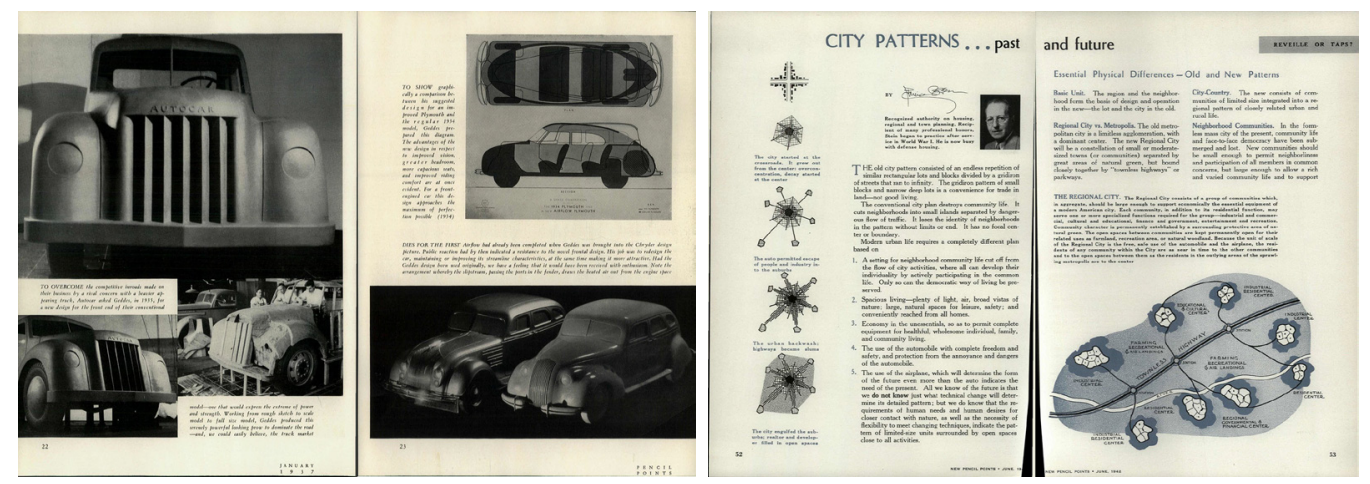

II secondo dopoguerra rappresentò un nuovo momento di rinnovamento creativo nell'ambito dei periodici, che raggiunse il suo apice negli anni Sessanta, in cui si assiste nuovamente alla nascita di numerose riviste autoprodotte in piccole tirature con periodicità irregolare, con un fenomeno che è stato concettualmente accostato a quello avvenuto negli anni Venti [Scott Brown 1968].

In questo periodo alcune riviste cessarono la loro pubblicazione e altre si trasformarono dal punto di vista del design grafico, mentre i formati rimasero sostanzialmente invariati. I disegni di progetto furono in larga misura sostituiti da fotografie, la tecnica del collage acquistò uno spazio sempre maggiore [Schmiedeknecht 20।8].

Pencil Points, che non aveva interrotto la pubblicazione durante gli anni della guerra, anticipa questo processo e nel numero di giugno 1942 cambia il nome in The New Pencil Points 
e inizia a trattare tematiche relative alla ricostruzione e alla pianificazione urbanistica. La grafica interna viene rinnovata con una composizione simmetrica tra le due pagine affiancate, movimentata da titoli e immagini passanti tra le due pagine e frequenti infrazioni della gabbia tipografica (fig. 8). Le rappresentazioni si modificano con l'inserimento frequente di plano volumetrie e viste assonometriche, accanto a piante e un largo utilizzo della fotografia. Le copertine diventano più elaborate dal punto di vista grafico, e cercano di stabilire un legame con i principali contenuti trattati nel numero. In breve tempo la

Fig. 9. Copertine di The new Pencil Points, giugno 1942 e novembre 1942 con illustrazione grafica; febbraio 1943 con grafia e collage.

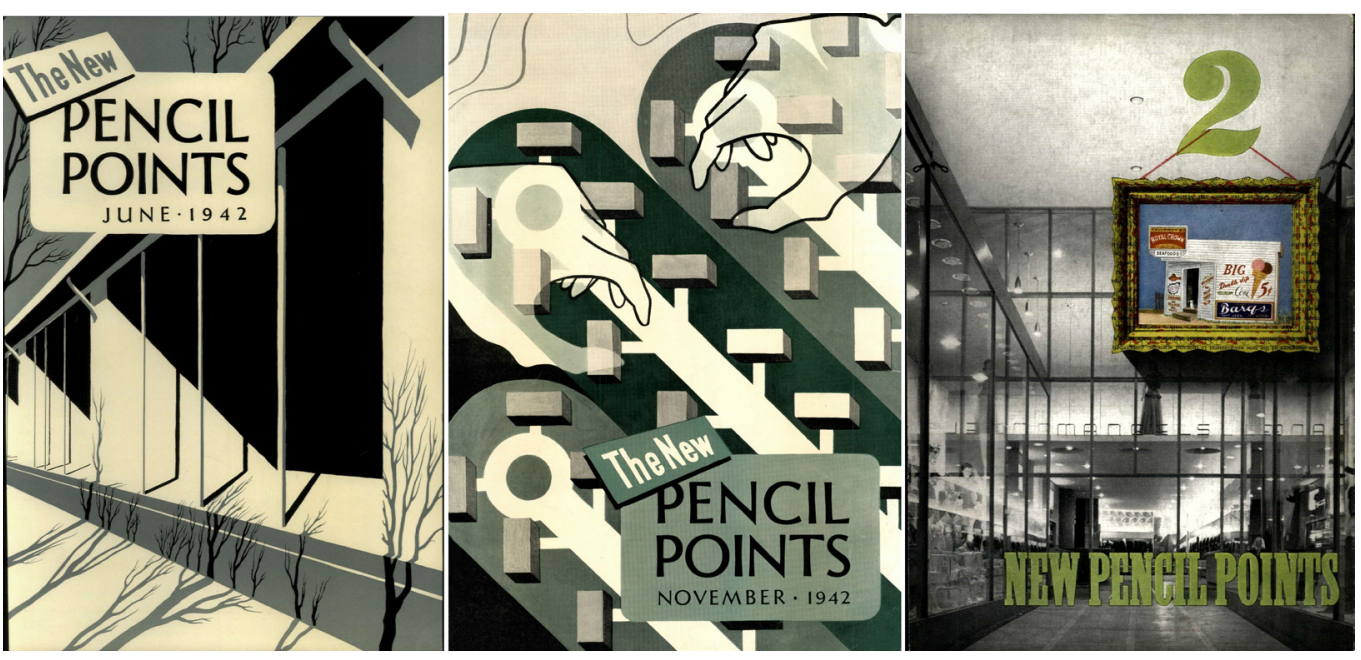

composizione grafica viene definitivamente sostituita da una fotografia di sfondo a tutta pagina (fig. 9).

A partire dal 1943, negli elaborati per i concorsi di architettura pubblicati sulla rivista fa la sua comparsa la tecnica del fotomontaggio, utilizzata per riunire porzioni di disegno con immagini fotografiche. Le prospettive fanno uso di colori vivaci, dalla forte valenza espressiva (fig. 10). II rinnovamento diventa molto rapido: nel gennaio 1944 la rivista prende il nome di Pencil Points. The magazine of architecture, sancendo il definitivo abbandono, già avvenuto di fatto, delle tematiche rivolte ai disegnatori. Pochi mesi dopo, ad agosto 1944 , lo modifica ancora in Pencil Points. The magazine of progressive architecture. È l'anno in cui Costantino Nivola assume la direzione artistica della rivista, dopo essersi trasferito in

Fig. 10. Concorso di progettazione Store Fronts of Tomorrow. Progetto premiato con menzione, di Whitney R. Smith, Architect, e Robert W. Dickinson, Pasadena. Da: The new Pencil Points, febbraio 1943.

Fig. I I. Copertine realizzate sotto la direzione artistica di Costantino Nivola, numeri da aprile settembre 1944.

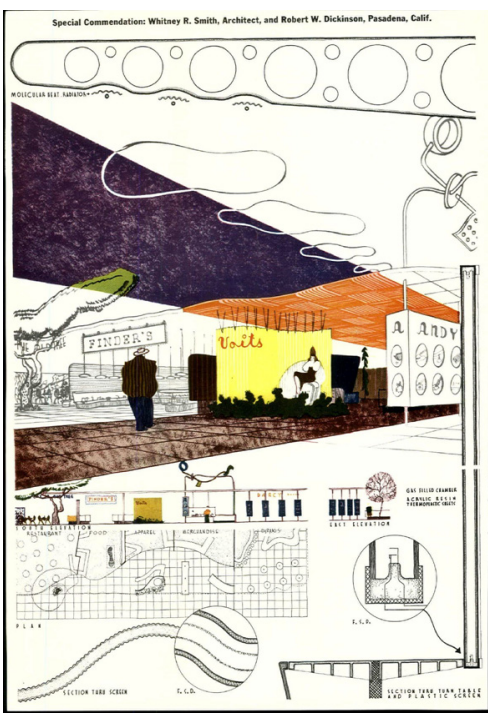


America e iniziato a frequentare gli artisti del Greenwich Village di New York. In continuità con il lavoro del precedente direttore Bernard Rudofsky, che aveva rimarcato attraverso la struttura grafica il passaggio a rivista di architettura modernista, Nivola crea una serie di copertine molto efficaci dal punto di vista della comunicazione visiva (fig. I I). I temi sono legati alla nuova architettura e cultura urbanistica favorite dal clima bellico, e al ruolo egemonico che gli Stati Uniti si preparavano ad assumere in ambito architettonico e non solo [Altea, Camarda 2015]. L'interno della rivista assume una veste molto più dinamica, grazie alle continue infrazioni della gabbia tipografica, l'inserimento di testi e immagini in posizioni oblique, l'alternanza di disegni e fotografie.

Osservando i disegni pubblicati in questo periodo si può notare come da una parte le piante si arricchiscono di elementi tecnici e costruttivi dettagliati, dall'altra le prospettive mirano sempre più a un effetto di comunicazione con il pubblico con un linguaggio semplice e attrattivo, che a volte sconfina del fumetto o nel collage. Interessante è la relazione sempre più stretta tra disegni e fotografie, anche con l'obiettivo di mostrare soluzioni innovative in grandi strutture in cemento armato e in acciaio. Si va sempre più in direzione di una chiarezza espositiva nella presentazione del progetto, spesso corredato di note scritte, attraverso la sintesi visiva di diversi elementi comunicativi (testo, disegno, fotografia) all'interno della pagina o all'interno del singolo elaborato grafico (fig. 12). II colore entra in maniera più diffusa nella rivista, con disegni stampati su fondo colorato o realizzati con tratti a colori. In sintesi, si assiste alla trasformazione dalla semplice rappresentazione del progetto alla sua narrazione, che si avvale di tutti i mezzi espressivi disponibili. Nello stesso periodo il titolo Pencil Points sulla copertina si riduce progressivamente dal punto di vista visivo per dare sempre maggior peso al sottotitolo Progressive architecture che diventerà il nuovo nome della rivista alla fine degli anni Quaranta. Con questo titolo la testata attraverserà le nuove innovazioni nel linguaggio grafico in direzione di una maggiore libertà espressiva a cavallo tra gli anni Cinquanta e Sessanta, che saranno oggetto di un prossimo studio.

Fig. 12. Progetto per funicolare e centro visitatori in Tennessee. Da: Progressive Architecture, dicembre 1947. || progetto è illustrato attraverso la pubblicazione di piante sezioni, prospettive fotografie, dettagli costruttivi.
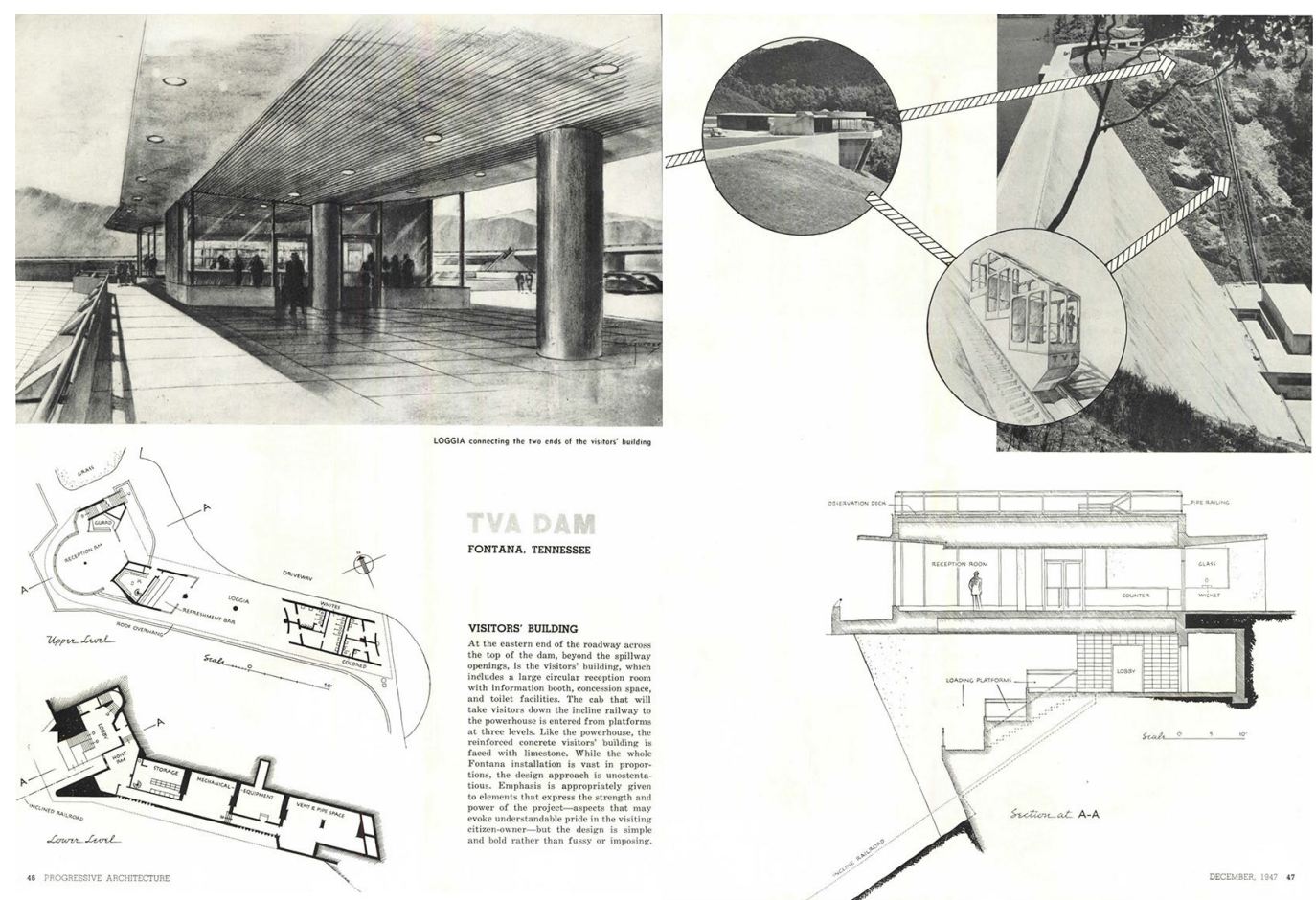

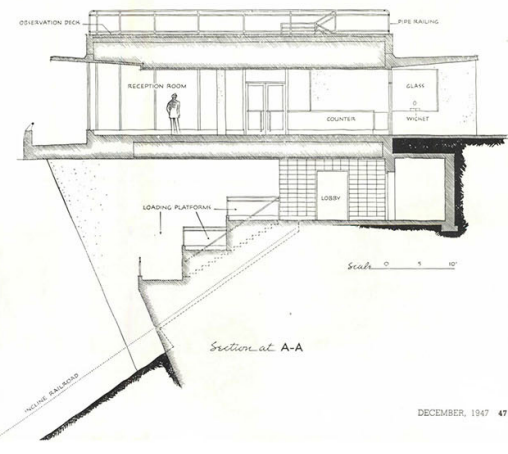




\section{Riferimenti bibliografici}

Altea G., Camarda A. (20 I5). Nivola. La sintesi delle arti. Nuoro: llisso edizioni.

Chinellato A., Noventa G. (20 I3). La superficie bianca. II prodotto editoriale tra storie e progetti. Padova: Libreria universitaria.

Di Battista N. (2017). Congedo da Domus. In Domus 1019, Dicembre 2017, pp. X-XI.

Hartman G., Cigliano J. (2004). Prefazione dei curatori. In: Pencil Points reader.A journal for the drafting room 1920-1943, pp. XIII-XIV. New York: Princeton architectural press.

Mertins D., Jennings M. (a cura di) (20 I0). G:AnAvant-Garde Journal of Art, Architecture, Design, and Film, 1923-1926. Los Angeles: Getty Research Institute.

Mulazzani M. (1997). Le riviste di architettura. Costruire con le parole. In F. Dal Co (a cura di). Storia dell'architettura italiana. II secondo Novecento, pp. 430-443. Milano: Electa.

Schmiedeknecht T., Peckham A. (20 I 8). Modernism and the Professional Architecture Journal: Reporting, Editing and Reconstructing in post-war Europe. London: Routledge.

Scott Brown D. (1968). Little Magazines in Architecture and Urbanism. In: Journal of the American Institute of Planners, volume 34, Issue 4, pp. 223-233.

Thacker A. (2017). Verso una mappa delle riviste moderniste. Alcune considerazioni di metodo. In: C. Patey, E. Esposito (a cura di). I modernismi delle riviste:Tra Europa e Stati Uniti. Milano: Ledizioni.

Autore

Manuela Piscitelli, Università degli Studi della Campania “Luigi Vanvitelli”, manuela.piscitelli@unicampania.it

Per citare questo capitolo: Piscitelli Manuela (2021).Il linguaggio grafico modernista nelle pagine di Pencil Points/The modernist graphic language in the pages of Pencil Points. In Arena A., Arena M., Mediati D., Raffa P. (a cura di). Connettere. Un disegno per annodare e tessere. Linguaggi Distanze Tecnologie. Atti del $42^{\circ}$ Convegno Internazionale dei Docenti delle Discipline della Rappresentazione/Connecting. Drawing for weaving relationship. Languages Distances Technologies. Proceedings of the $42^{\text {th }}$ International Conference of Representation Disciplines Teachers. Milano: FrancoAngeli, $1029-1046$. 


\title{
The Modernist Graphic Language in the Pages of Pencil Points
}

\author{
Manuela Piscitelli
}

\section{Abstract}

The paper analyzes the characteristics and the evolution in the communication of architectural design between the 1920s and 1940s through the study of the American magazine Pencil Points. The twenties were a moment of strong impulse in the field of architectural periodical publishing, which became one of the main channels for the debate and the diffusion of new ideas and images. The graphic language had a rapid evolution in the following years, in parallel with the architectural language and the visual composition of the printed page. For this reason, contemporary magazines are a privileged observatory, with a wide repertoire of images and graphic solutions testifying the evolution of the techniques of representation and communication of architecture. The choice of the magazine Pencil Points is due to the long period of publication, to its well-defined editorial structure, not linked to a specific artistic current, and to the regular periodicity, which allowed to observe the transformations in the presentation of visual contents.

Keywords

graphic language, modernist architecture, design representation, illustrations, magazines.

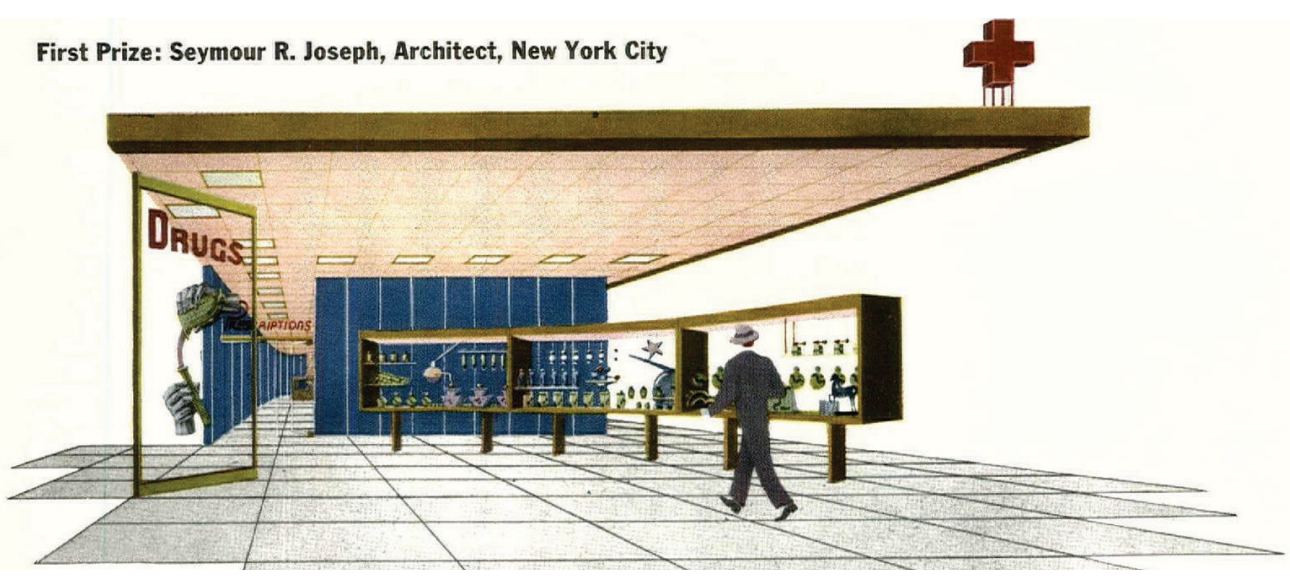


Since its publication at the end of the 19th century and for a good part of the 20th century, the magazine has been the media that has most contributed to the cultural debate in various sectors, including architecture, and to the diffusion of ideas, tastes, trends and images between distant geographical areas. As the director of Domus wrote in his farewell, "a magazine must be able, yes, to show and know projects, products, thoughts that our time produces but, above all, to tell the stories that make them possible, the stories that underlie them" [Di Battista 20 17].

The narrative first of all implies choices in the contents, but equally significant are the choices of the expressive modes through which these contents are conveyed, which make their study particularly interesting to trace a history of the evolution of architectural project representation and communication. From the analysis of a magazine, in fact, emerge themes such as visual design, graphic design, the use of photography or architectural drawing, the relationship between images and text. The presence of advertising is also a significant element in the study of a periodical, because of its double value of communication with the readers and the productive world, and of support for the magazine.

"The codes at play in periodical publications are numerous: layout (amount of white space, number of columns); fonts; volume format; periodicity (weekly, monthly, quarterly, irregular); quality of illustrations (in color or not, type of technology used for reproduction); presence and placement of advertising space; quality of paper and binding; sales and distribution networks; financial terms and any remuneration to contributors; editorial structure; and even the type of materials published" "Thacker 2017, p. 22].

The present study deals with these issues through the analysis of the American magazine Pencil Points, whose remarkable circulation and longevity allows us to appreciate the transformations, both in the graphic language of the magazine and in the projects presented in its pages, in a period that covers most of the twentieth century and sees the affirmation of modernist language, which the magazine took as its central theme.

Pencil Points was founded in 1920 as a monthly magazine, with the aim of connecting designers and architects. Initially linked to the Academy of Fine Arts, it was one of the main vehicles for the dissemination of new trends in modernism, testifying a particular historical moment in the field of architecture and design in the United States. On its pages, between

Fig. I.Text and illustrations on the execution of perspective drawing. From: Pencil Points,

Fig. 2. Warren \& Wetmore Architects Elevations for the project of the Italian Embassy of the Italian Embassy in Washington D. C. From: Pencil Points, vol. 6, n .9, September 1925. The project is illustrated through the publication of the drawings of the plans of the various levels and the elevations.
PERSPECTIVE DRAWING, PART II By PaUl VALENTI

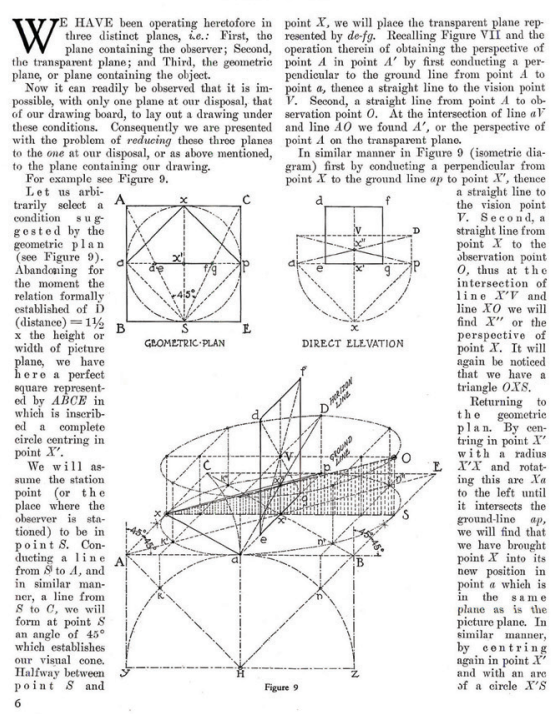

PENCIL POINTS

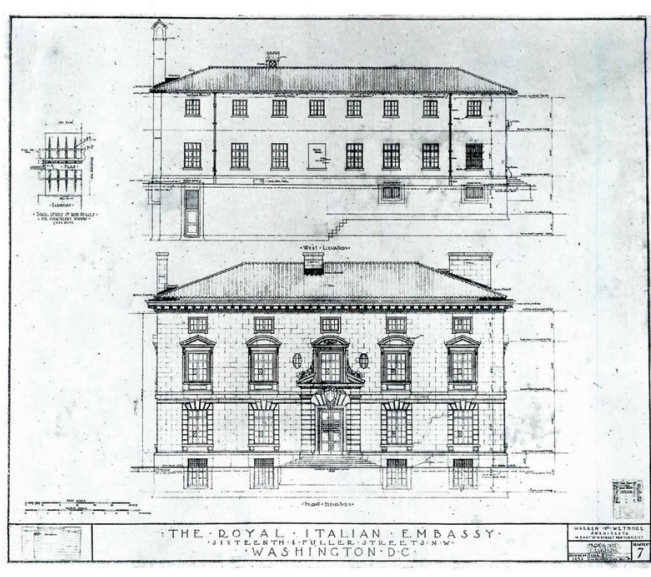

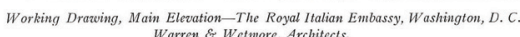


the twenties and forties, the history and ideas of a new generation of American and European architects were presented: Russel Pope, Francis Bacon, Walter Gropius, Richard Neutra, Le Corbusier, Marcel Breuer, Norman bel Geddes, Mies Van der Rohe, whose theory and projects it conveyed. Starting with only 22 pages in 1920, ten years later it published 152 pages with a circulation of 21,000 copies. By 1940 it was one of the most widely distributed American architectural magazines, alongside Architectural Record and Architectural Forum. In 1944, a new title, Progressive Architecture, marked its transition to a design and urban planning magazine. With this style it remained one of the most influential magazines in the field for the next 50 years, until it closed in 1995 [Hartman, Cigliano 2004].

The founding period of Pencil Points coincides with a moment of great diffusion of the magazine as a medium for the architectural debate. The great masters of architecture, in fact, chose it as a tool for the diffusion of their ideas, even founding their own, such as L'esprit nouveau by le Corbusier (1920-1925) and G: Material zur elementaren Gestaltung by Mies van der Rohe (1923-1926), which were used as a channel of debate for the avant-garde. While L'Esprit Nouveau had a traditional typographic approach, in G the graphic research

Fig. 3. Pencil Points, header in vol. I, n. I, June 1920; new simplified header in vol. 6, n. II, November 1925; first cover in vol. 10, n. II, November 1929 illustrated first cover in vol 14 , I lanury 1933; change in the position change in the position the cover of the cover of vol.16, n. I. January 1935

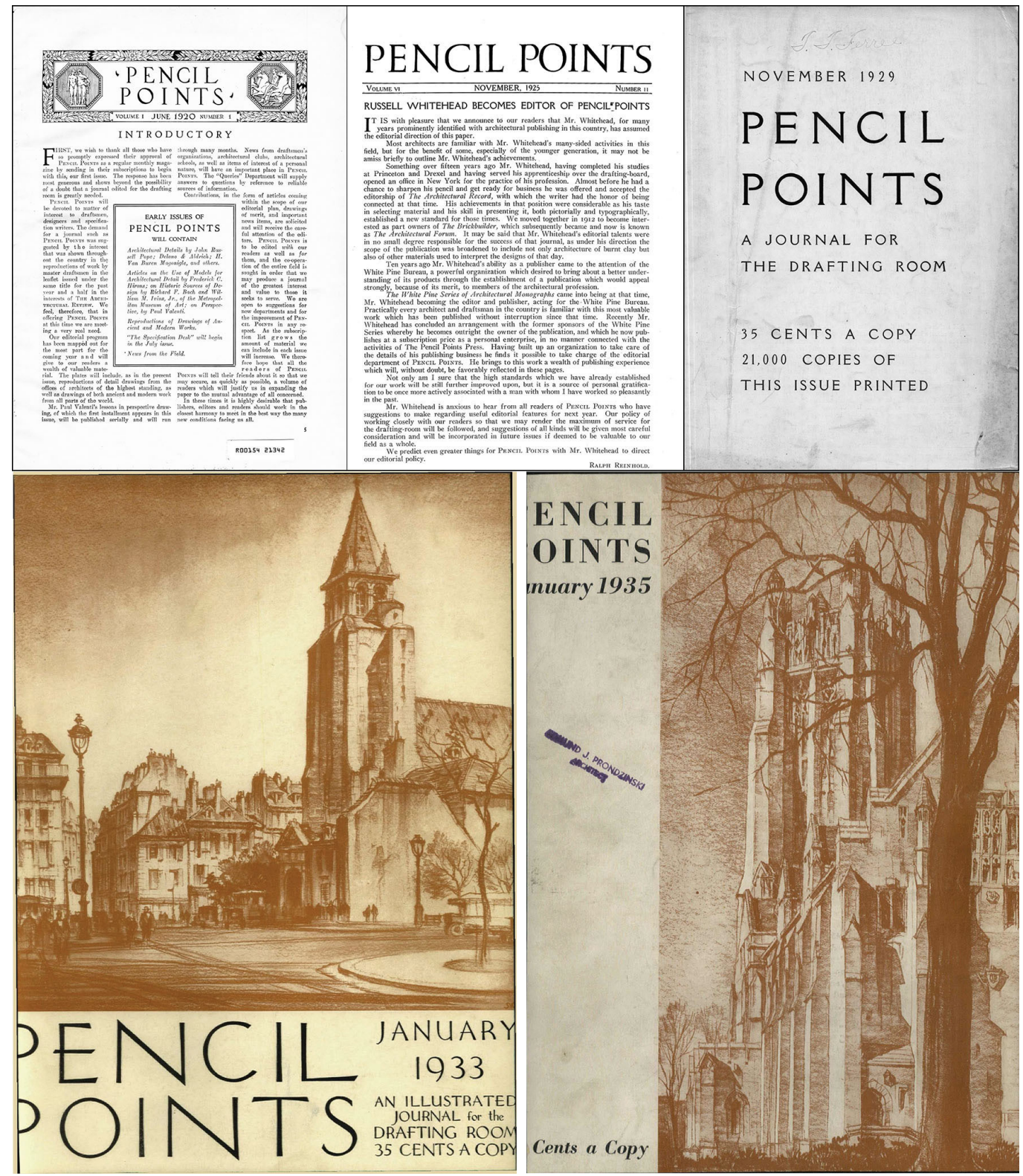


was part of the communicative project, as evidenced by the constructivist typographic layout created by El Lissitzky [Mertins 20 I0]. The phenomenon is widely spread in all geographical areas in this period, with magazines also linked to artistic movements and the diffusion of their values. Next to the already mentioned $G$ and L'Esprit Nouveau, we find Bauhaus (1928-1933) in Germany, Sovremennaia Arkhitektura (1926-1930), Lef (1923-1925) and Veshch (1922) in Russia, Wendingen (1918-1931) and de Stijl (1917-1931) in Holland, and all the futurist periodicals in Italy such as Valori plastici (1918-1921), Lacerba (1913-1915), Noi (1917-1920 and 1923-1925).

Around the Twenties, therefore, there was a very complex phenomenon in periodical publishing, characterized by publications of short duration and often with irregular intervals, sharing the desire to bring together in a new language the graphic, typographic and editorial aspect with the content to be conveyed. The aesthetic and visual innovations of Cubism, the abandonment of the figurative representation of reality, the fragmentation of the order of the page brought about by Futurism, and the typographic experiments of the Bauhaus, were all elements that contributed to the visual renewal of the editorial products through which the avant-gardes communicated their ideas and involved the field of architecture [Chinellato and Noventa 20I3].

Fig. 4. George D. Recher, project for a Drug store. Proposal submitted to the Modernize main street competition. From: Pencil Points, vol. I6, n. I0 October 1935.

Fig. 5. Giuseppe Vaccaro, project for the Palace of the Post Office in Naples. Model, plan and perspective of the centra atrium From Pencil Points, atrium. From: Pencil Points,
vol. I6, n. I, January 1936.
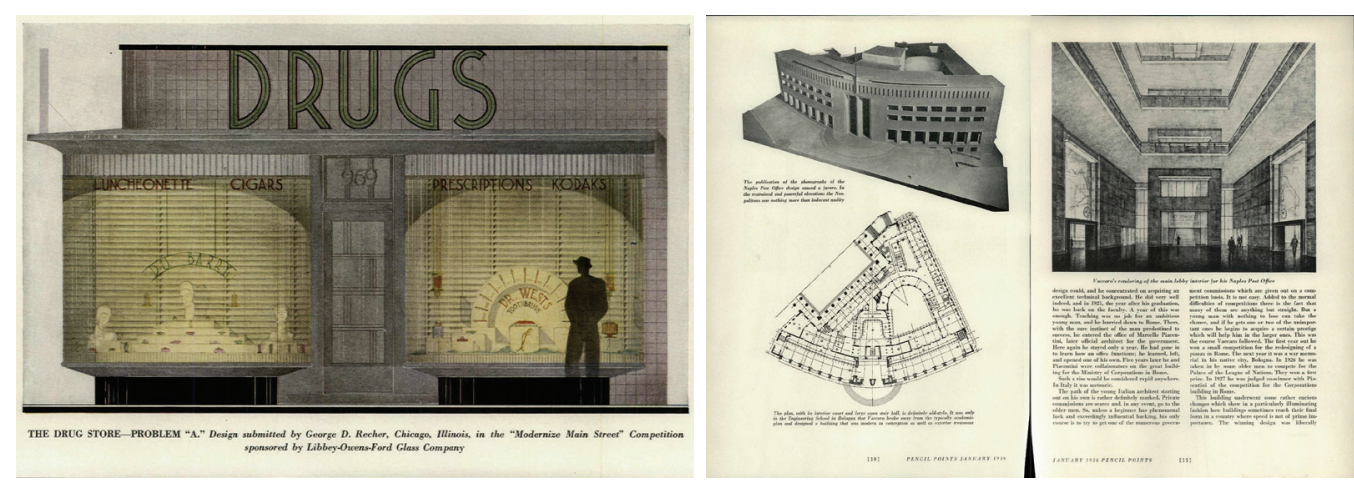

The choice not to use these magazines for the present study is due to the intention to cover a longer time frame, analysing the transformations in a magazine with its own well-defined editorial structure, not linked to a specific artistic current, and a regular periodicity, to better appreciate the transformations that more generally occurred in the representation and communication of the architectural design.

In this first phase, unlike the magazines linked to the avant-garde movements characterized by innovative graphic layouts, Pencil Points presents a traditional graphic layout, with a two-column grid, the use of the capital letter at the beginning of the paragraph, and few variations in the typographic fonts. Text and images only in a few cases share the space of the page, more often the drawings are printed in separate plates, numbered and accompanied by captions. Since the magazine was initially aimed at draftsmen and the Academy of Fine Arts, the themes of the drawings are often of a practical nature, with illustrations for the setting of a perspective or the execution of a drawing, graphic techniques, suggestions for the use of pencils and ink, the execution of shadows and light and shade, alternating with reproductions of plates of classical architecture and drawings of architectural designs (figs. I, 2). In some issues, graphic analysis of building geometries is proposed. Photography has a marginal weight in the pages; illustration is almost exclusively entrusted to drawing with the various expressive techniques. Regarding the methods of representation, the prevalent method is the perspective in the form of freehand sketch or geometrically constructed. Much used is also the method of orthogonal projections, in plan and elevation. Sections are rare and axonometry is completely absent. 
From the November 1925 issue, under the new editorial direction of Russel Whitehead, a timid attempt to modernize the magazine's graphics began, starting with the header, which was simplified by abolishing decorative motifs, resulting in greater concision and formal cleanliness.

The layout of the page continues to make use of the double column, but the captions of the tables are inserted in the facing page giving a greater breath to the graphic structure. The images are still mainly perspective views.

From the number of November 1929, the magazine has a true and proper cover, although without images, but containing only information about the magazine that were previously included in the header on the first page. This innovation coincides with a significant increase in the number of pages of the issue, due to the inclusion of numerous advertisements both at the beginning and at the end of the magazine. The old header is reproposed on the first page of the magazine after the advertising insert that fills up to 60 pages at the beginning of the issue. The advertising pages are characterized by a greater dynamism in composition and typographical variations, compared to the layout of the magazine that remains anchored to the old two-column grid with little integration between text and images.

From January 1933, the cover becomes illustrated. The title's name moves down to a leftaligned position, a position that will change several times in the following years, leaving the image as the dominant visual element. It is always a drawing executed and published in colour, typically a perspective view of a building (fig. 3). Inside, although drawings continue to predominate, photographs gradually gain more weight. In the following years, we can see a

Fig. 6. Garden city project. Axonometric cutaway with construction details of a brick house. From: Pencil Points, vol. 16, n. 8 , August 1936.

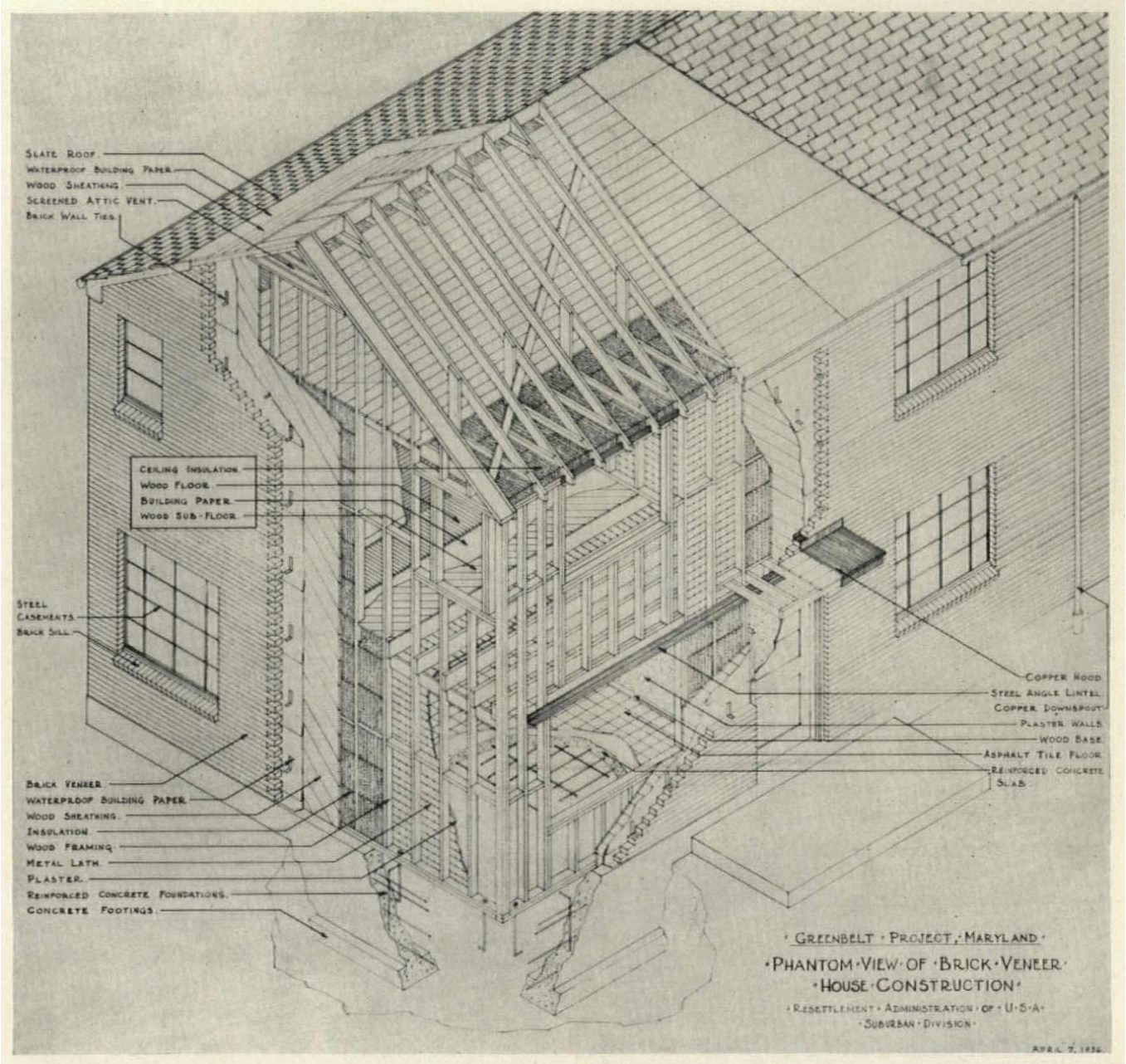


turning away from the themes aimed at draftsmen and a greater focus on idea competitions and the presentation of modernist architecture projects from different geographical areas, contributing to the circulation of ideas and images (fig. 4). A section devoted to contemporary European architects and their designs was introduced. In this section, the January 1936 issue presents the Italian Giuseppe Vaccaro and illustrates several of his projects, including the Faculty of Engineering in Bologna and the Post Office Building in Naples (fig. 5). The graphic illustrations of the designs are mainly drawings and, to a much lesser measure, photographs. Among the drawings, perspective views still prevail, both external and internal, accompanied by the plan of the building. The axonometric representation makes its appearance, also in the form of cutaway to show the construction details (fig. 6). At the same time, the page layout becomes freer, with greater integration between text and images, and the composition on the double page allows the publication of larger images by exploiting the space of the pages side by side. The covers abandon the image that characterized them and are often limited to a basic colour and a few graphic elements, on which the name of the header stands out and becomes the main visual element, with a more modern setting in line with the themes of essentiality of modernist architecture that were published. The issues begin to be dedicated to a topic or an architect, as in the case of the projects for the 1939 New York World's Fair, published in the December 1936 issue, or the January 1937 issue largely dedicated to Norman Bel Geddes and his futuristic transportation projects. Design burst into the pages of the magazine with models of cars, trains, airplanes, the first ideas of mobile homes. Photographs of models and objects, also taken during the production phase, begin to quantitatively surpass the drawings (fig. 7).

The post-World War II period represented a new moment of creative renewal in the field of periodicals, which reached its peak in the 1960s, when we again assist to the birth of numerous self-published magazines in small print runs with irregular periodicity, with a

Fig. 7. Norman Be Geddes, Design of the new Plymouth. Models and diagram comparing with previous version in plan and section. From: Pencil Points, vol. 17, n. I. January 1937.

Fig. 8. Diagrams of cities of the past and future. From: The new Pencil Points, n. 6, June 1942.
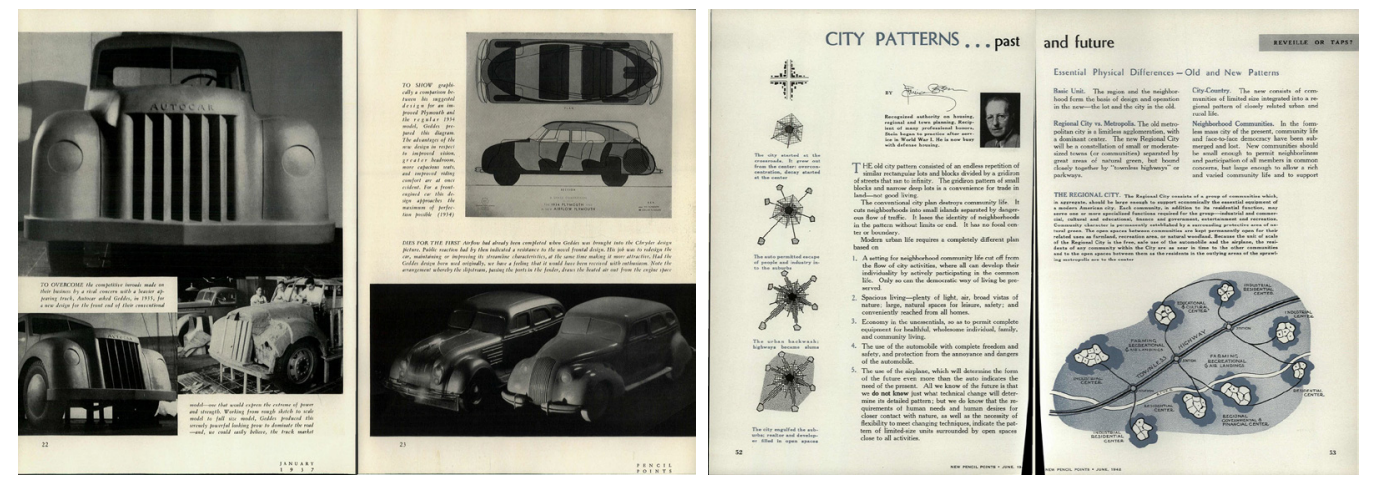

phenomenon that has been conceptually compared to what happened in the 1920s [Scott Brown 1968].

During this period, some magazines ceased publication and others were transformed in terms of graphic design, while the formats remained essentially unchanged. Design drawings were largely replaced by photographs, and the collage technique gained more space [Schmiedeknecht 2018].

Pencil Points, which had not interrupted publication during the war years, anticipates this process and in the June 1942, issue changes its name to The New Pencil Points and begins to deal with themes related to the reconstruction and urban planning. The internal graphics are renewed with a symmetrical composition between the two facing pages, enlivened by titles and images passing between the two pages and frequent infractions of the typographic grid (fig. 8). Representations change with the frequent inclusion of volumetric plan views and axonometric views, alongside plans and an extensive use of photography. The covers become 
more graphically elaborate and attempt to establish a link to the main content covered in the issue. In a short time, the graphic composition is permanently replaced by a full-page background photograph (fig. 9).

From 1943, the photomontage technique, used to combine portions of a drawing with photographic images, made its debut in the drawings for architectural competitions published in the magazine. The perspectives make use of bright colours, with a strong expressive value (fig. 10). The renewal becomes very rapid: in January 1944, the magazine takes the name of

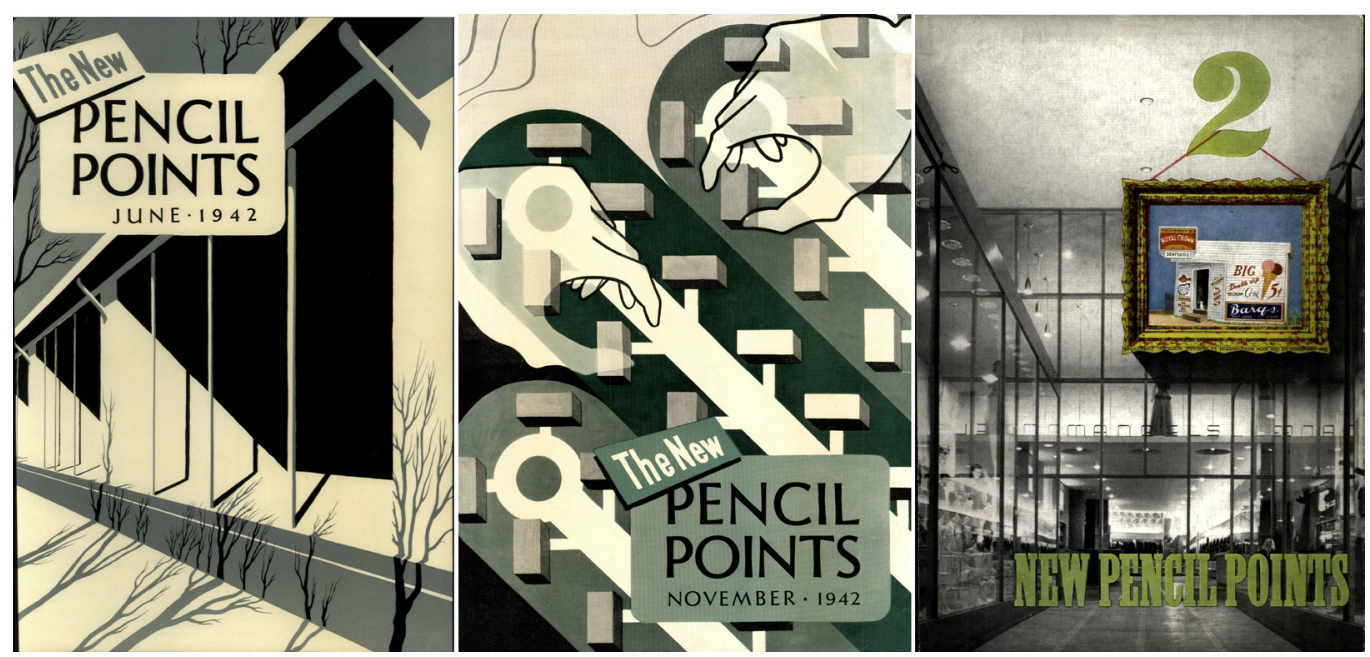

Pencil Points. The magazine of architecture, ratifying the definitive abandonment, which had already taken place, of the themes addressed to draftsmen. A few months later, in August 1944, it changed again in Pencil Points. The magazine of progressive architecture. In the same year Costantino Nivola assumes the artistic direction of the magazine, after having moved to America and begun to frequent the artists of the Greenwich Village of New York. In continuity with the work of the previous director Bernard Rudofsky, who had emphasized through the graphic structure the transition to a magazine of modernist architecture, Nivola creates a series of very effective covers from the point of view of visual communication (fig. I I). The themes are related to the new architecture and urban culture favoured by the war climate, and to the hegemonic role that the United States was preparing to assume in architecture
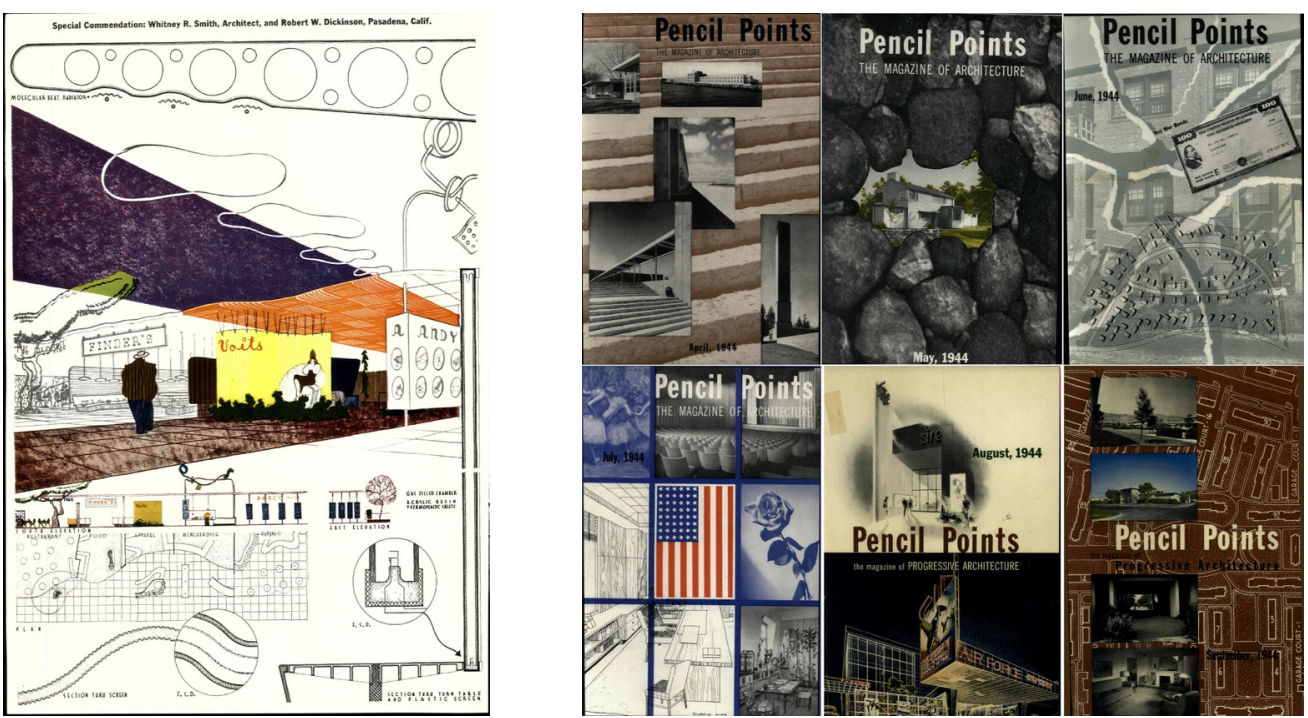
and beyond [Altea, Camarda 2015]. The internal of the magazine takes on a much more dynamic look, thanks to the continuous breaches of the typographic cage, the insertion of texts and images in oblique positions, and the alternation of drawings and photographs.

Observing the drawings published in this period we can notice how on the one hand the plans are enriched with technical and constructive detailed elements, on the other hand the perspectives increasingly aim at a communication effect with the public with a simple and attractive language, that sometimes borders on the comic strip or on collage. Interesting is the increasingly close relationship between drawings and photographs, also with the aim of showing innovative solutions in large reinforced concrete and iron structures. There is an increasing trend towards expositive clarity in the presentation of the project, often accompanied by written notes, through the visual synthesis of different communicative elements (text, drawing, photograph) within the page or within the single graphic work (fig. 12). Colour enters the magazine in a more widespread way, with drawings printed on a coloured background or made with colour lines. In synthesis, there is a transformation from the simple representation of the project to its narration, which makes use of all the available expressive means. In the same period, the title Pencil Points on the cover is progressively reduced from a visual point of view to give greater weight to the subtitle Progressive architecture, which will become the new name of the magazine at the end of the 1940s. With this title the magazine will go through the new innovations in the graphic language in the direction of a greater expressive freedom at the turn of the fifties and sixties, which will be the subject of a future study.

Fig. 12. Design for funicular and visitor centre in Tennessee. From: Progressive Architecture, Decembe 1947. The project is illustrated through the publication of plans, sections, perspectives, photographs, and construction details.
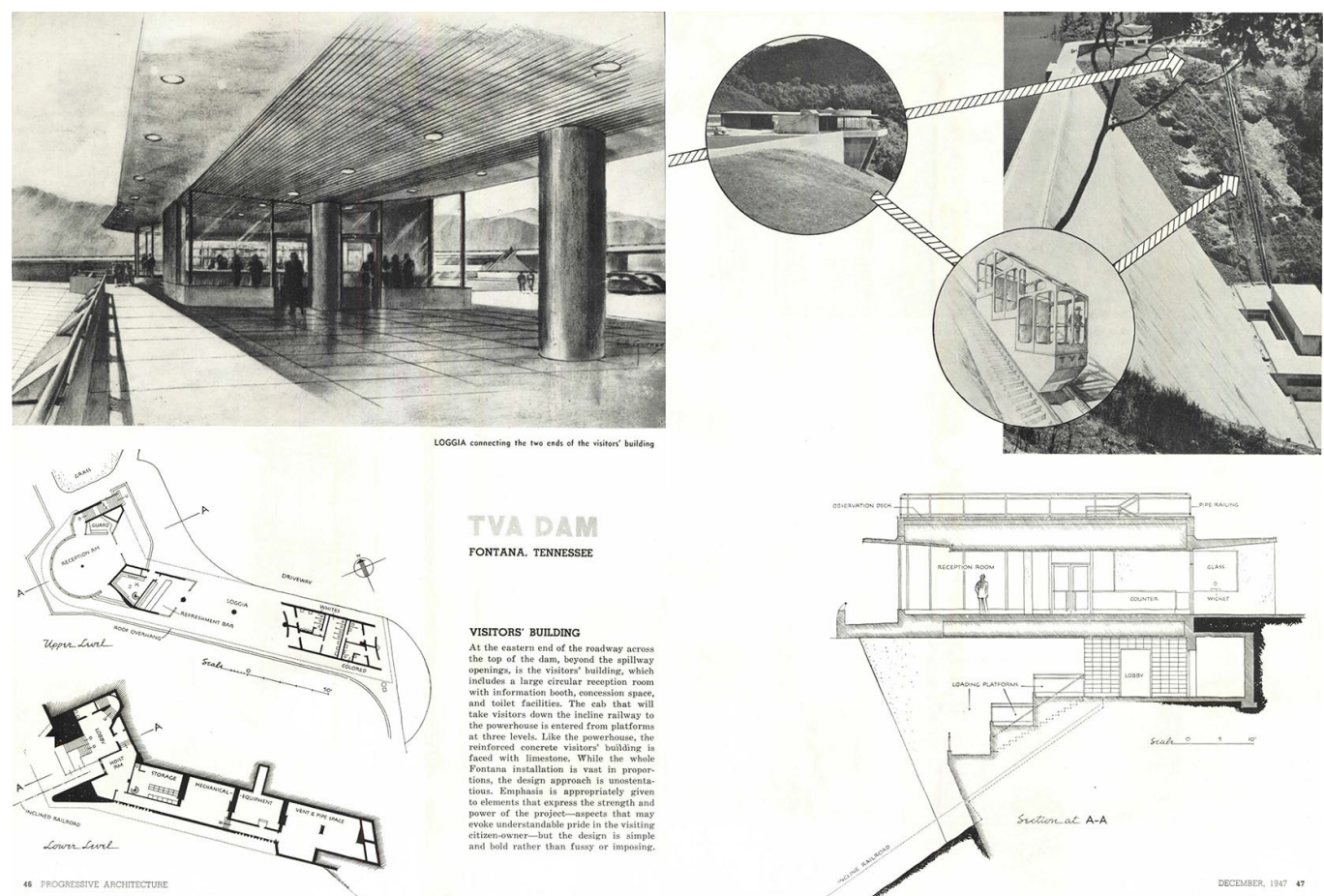

THA DAN

FONTANA. TENNESSE
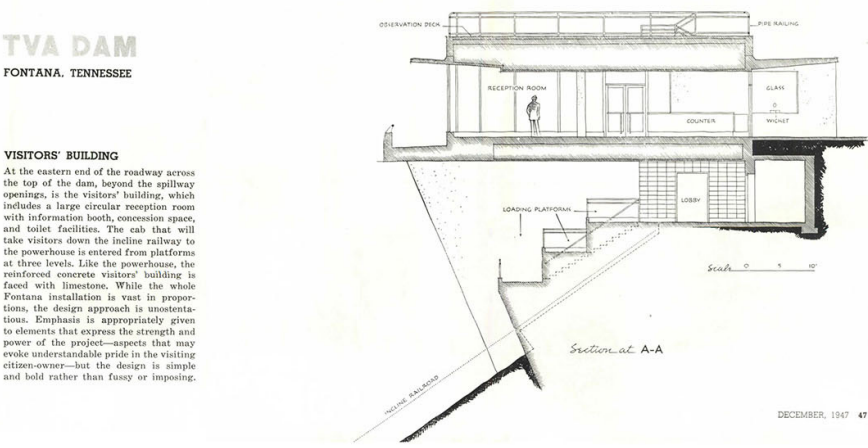


\section{References}

Altea G., Camarda A. (20I5). Nivola. La sintesi delle arti. Nuoro: llisso edizioni.

Chinellato A., Noventa G. (20 I3). La superficie bianca. II prodotto editoriale tra storie e progetti. Padova: Libreria universitaria.

Di Battista N. (2017). Congedo da Domus. In Domus 1019, Dicembre 2017, pp. X-XI.

Hartman G., Cigliano J. (2004). Prefazione dei curatori. In: Pencil Points reader.A journal for the drafting room 1920-1943, pp. XIII-XIV. New York: Princeton architectural press.

Mertins D., Jennings M. (a cura di) (20 I0). G:AnAvant-Garde Journal of Art, Architecture, Design, and Film, 1923-1926. Los Angeles: Getty Research Institute.

Mulazzani M. (1997). Le riviste di architettura. Costruire con le parole. In F. Dal Co (a cura di). Storia dell'architettura italiana. II secondo Novecento, pp. 430-443. Milano: Electa.

Schmiedeknecht T., Peckham A. (20 I 8). Modernism and the Professional Architecture Journal: Reporting, Editing and Reconstructing in post-war Europe. London: Routledge.

Scott Brown D. (1968). Little Magazines in Architecture and Urbanism. In: Journal of the American Institute of Planners, volume 34, Issue 4, pp. 223-233.

Thacker A. (20 17). Verso una mappa delle riviste moderniste. Alcune considerazioni di metodo. In: C. Patey, E. Esposito (a cura di). I modernismi delle riviste:Tra Europa e Stati Uniti. Milano: Ledizioni.

\section{Author}

Manuela Piscitelli, Università degli Studi della Campania “Luigi Vanvitelli”, manuela.piscitelli@unicampania.it

To cite this chapter. Piscitelli Manuela (2021).Il linguaggio grafico modernista nelle pagine di Pencil Points/The modernist graphic language in the pages of Pencil Points. In Arena A., Arena M., Mediati D., Raffa P. (a cura di). Connettere. Un disegno per annodare e tessere. Linguaggi Distanze Tecnologie. Atti del $42^{\circ}$ Convegno Internazionale dei Docenti delle Discipline della Rappresentazione/Connecting. Drawing for weaving relationship. Languages Distances Technologies. Proceedings of the $42^{\text {th }}$ International Conference of Representation Disciplines Teachers. Milano: FrancoAngeli, 1029 - I 046. 